\title{
Measuring the Impact of Some Determinants of Return on Investment in Industrial Companies in Aqaba City
}

\author{
Farouq Ahmad Alazzam \\ Management and financial science branch, Al-Balqa' Applied University, Jordan \\ E-mail: farouq_20000@yahoo.com
}

Received: August 4, 2014 Accepted: August 13, 2014 Published: August 30, 2014

doi:10.5296/bms.v5i2.6067ＵRL: http://dx.doi.org/10.5296/bms.v5i2.6067

\begin{abstract}
The main objective of this study is to measure the effect of some variables to the return on investment in industrial companies in Aqaba city. It has been found that were three determinants of a positive impact on return on investment they are an indebtedness, automation and growth rate, while the two variables found to have a negative impact, the liquidity ratio and the rate of turnover in accounts receivable. The study recommended that companies resort debt in financing on their operations especially in asset purchase and rely on fixed assets at their production process and reduce the liquidity ratio as much as possible and to examine the reasons for the negative relationship between table circulation of accounts receivable and the rate of return on investment and to overcome them or reduce them.
\end{abstract}

Keywords: Return on investment, Aqaba, Alazzam, Industrial companies 


\section{Introduction}

The focus of the economic units to maximize the profitability, and to achieve this goal there are techniques, methods and basis these units rely on, during its economic operation and maximize the profits depends on the success of the facility at effect on the elements of the profitability of expenditures and revenues, what is required to control expenditures and increase revenue and to achieve it in many and varied ways resort to facility.

This has increased the attention of researchers to discover the determinants of positive and negative profit to promote the first one and run down the other. Some tools used in this context such as, financial analysis tools through the financial ratios that have to do with variable profitability. Has been relying on statistics in this field, the most importantly it is using linear regression analysis to link Financial Ratios to profitability.

The identification of the determinants of the profitability by using regression analysis to a particular community of economic units, will be limited to these units of the different nature and circumstances from other units. It conducted several studies to various economic units in Jordan in this regard, but by researcher's knowledge, it had not been made any study concerning at industrial companies in Aqaba special economic zone (ASEZ).

\section{The Study Problem}

The problem with this study is lack of knowledge of the effect in each about the debt ratio, the liquidity ratio, the percentage of automation, the growth rate and the rate of circulation of accounts receivable on the rate of the return on investment in industrial companies in Aqaba city, therefore, the study questions are:

- What is the effect of the change in the debt ratio on the return on investment in industrial companies in Aqaba city?

- What is the effect of the change in the liquidity ratio on the return on investment in industrial companies in Aqaba city?

- What is the effect of the change in the ratio of automation on the return on investment in industrial companies in Aqaba city?

- What is the effect of the change in the growth rate on the return on investment in industrial companies in Aqaba city?

- What is the effect of the change in the rate of circulation of accounts receivable on the return on investment in industrial companies in Aqaba city?

\section{The Importance of the Study}

Profitability represents the focus of any economic unit, the main objective of any facility is to achieve the profits to be able to continue and achieve the goal of owners and investors from an adequate return from their money on their investments. So the administration is striving to raise the rate of return on investment, there are several ways, steps and determinants, 
administration can be based on them to achieve this goal, this study will address some of the most important of these determinants to clarify its impact financially and morally on the return on investment through his studies about the important segment of industrial companies stationed in Aqaba city, which according to the researcher's knowledge lacks much to such studies. The privacy of Aqaba city after it has been converted into a special economic zone to attract various local and foreign investments and therefore such study results are an incentive for new investors turnout on investment and at the same time, the existing guidance to companies how to maximize profitability.

\section{Purpose}

The study aims to analyze and build a regression model linking the independent explanatory variables which is debt ratio, liquidity ratio, percentage of automation, growth rate and rate of circulation of accounts receivable on the dependent variable represented by rate of the return on investment in industrial companies in Aqaba city, and indicate the effect of each independent variable, in order to help these companies towards increasing profitability through the management of these independent variables.

\section{Methodology}

The study consists and rely on a standard curriculum through multiple linear regression analysis of the data collected from the members of the study sample.

\section{Society - Study Sample}

The study population consists of industrial companies in Aqaba city, shortened the study sample of 10 companies, which characterized by its age over 12 years- capital of more than one million Dinars and earnings throughout the years from 2001 to 2012.

\section{Analysis}

Was obtained the required data for the analysis of financial books for the study sample for a period of 10 years, which is from 2001 to 2012.

\section{Statistical Methods and significance Level}

0.05 was adopted as the level as a significance for this study. The Measurements were calculated following statistical Kolmogorov-Smirnov Z, Collinearity Statistics, Extraction, Durbin-Watson, $\mathrm{R}, \mathrm{R}^{2}$, t-test for as a significance changes, $\mathrm{f}$ test for as a significance regression model.

\section{The Definition of Study Variables}

Debt Ratio = liabilities / assets

Liquidity ratio $=$ current assets $/$ current liabilities

automation Ratio of the production process which turning from manual to automatic style = fixed assets / total assets 
growth rate $=($ sales of the current year - sales last year $) /$ sales last year

Accounts receivable turnover $=$ annual sales/ accounts receivable average

Return on investment $=$ net profit $/$ total assets

\section{Previous Studies}

Jaradat study ( 2012 ), this study aims to test the impact of inflation, the interest rate, workers' remittances and liquidity of the stock on the stocks returns during the period (1980-2011). To achieve this objective. The results revealed the existence of a causal relationship between all the variables, and the study found apositive relationship between stock returns and inflation, workers' remittances and liquidity of the stock, but there was a negative relationship between interest rates and stocks returns.

Borass staudy (2012), this study investigates the investment- cash flow sensitivity, the impact of size, and dividend payout policy on this sensitivity. Using panel data for 60 industrial firms listed in Amman Stock Exchange (ASE) over the period of 2000-2009, the study reports evidence suggesting that firms facing financial constraints have higher invest . The results also indicate that investment-cash flow sensitivity is negatively related to the payout ratio and size, which suggests the positive relationship between investment cash flow sensitivity and existence of financing constraints.

Noi Study (2010), the purpose of this study is to address the dilemmas on the extent to the efficient banking of Algerian banks through the use of certain financial ratios, the study found that these banks possess efficiently to bring the elements of production and savings allow diversification of products, but they do not have the capacity to control their costs. This study recommended that to raise the increase of efficiency in Algerian banks with increase their independence, improve the efficiency of the human element and updating the banks.

Gryglewicz Study (2008), this study aimed to identify the impact of each of the liquidity and solvency funding of joint stock companies. The study reported that companies seek the choice of an appropriate capital structure. The companies face uncertainty regarding cash flows which is a cash flows expected and uncertain, The study found that there is a positive relationship between dividends and cash flows.

Al Qdah Study (2008), the study aimed to identify the determinants of the performance of Jordanian Public Shareholding Companies that listed in Amman Stock Exchange and listed on the first and second two markets for the years of 2000 to 2006, has been using the regression equation, which was estimated by the method of least squares. The study found that the rate of profitability of the company depends on its capital structure. And that there is a positive relationship between the rate of Profitability and maturity of the company, and that the rate of the company's profitability in the current year depends on the rate of Profitability for the previous year. The most important thing has recommended by the study is that on the companies involved study by indicating financial and accounting information more accurately. 
Konstandian Study (2007), this study aimed to identify the necessary techniques to deal with deposits when they are planning to banks work, and show the weaknesses of the banks at the level of other banks, at the level of the industrial sector, and at the level of the economy as a whole. The study found that there is a positive relationship between deposits and liquid assets and The level of efficiency between the banks, either at the level of industry and the economy as a whole was not such a relationship existed.

Sheikh Study and else (2007), the study aimed to identify the ability of financial ratios style in the process of evaluating the performance of economic projects, And to identify the difficulties that limit the effectiveness of the financial analysis in this style. The most important findings of this study that the construction of the financial ratios of the financial statements that are based on estimates and interpretations of accounting does not reflect the different methodologies, policies and accounting treatments related in its preparation, making it not reflect the true reality of the project accurately.

The Study of Khasharma and Qaqeesh (2000), the study aimed to identify the factors affecting on the Profitability of insurance companies in Jordan which achieve a profit, The influencing factors on the degree of the loss of companies that lose money. The most important findings of the study the existence of a positive relationship between the return on investment and between all of the advertising and the size of the company and the company's age. there is a positive relationship between the proportion of debt and profitability in companies that make a profit, The an inverse relationship between Ratio debt and profitability in companies that make a loss.

\section{Testing Some of the Important Conditions for the Multiple Linear Regression Mode}

It Was confirmed the following hypotheses and should be available even the form is truthful and able to be predictable:

\subsection{Testing the Normal Distribution of the Independent Variables}

Indicates Table (1) that all the data of independent variables and the dependent variable follow a normal distribution where all levels of significance for viewing Kolmejrov Testing (Kolmogorov-Smirnov Z) bigger than 0.05.

\subsection{Diacritics Independent Variables with Dependent Variable}

Table (1) shows that all the independent variables Diacritics with dependent variable bigger than acceptance criterion which is 0.30 , which means that the independent variables explain or Iather in the dependent variable is statistical

Table (1). Results of test of normal distribution, correlation between the independent variables and the diacritics of the independent variables

\begin{tabular}{|c|l|l|l|l|l|}
\hline & Kolmogorov-Smirnov Z & Collinearity Statistics & \\
\hline Variable & Test value & sig & Tolerance & Vif & Diacritics \\
\hline debt rate & 1.14 & 0.147 & 0.32 & 3.12 & 0.34 \\
\hline
\end{tabular}




\begin{tabular}{|l|l|l|l|l|l|}
\hline $\begin{array}{l}\text { liquidity } \\
\text { ratio }\end{array}$ & 1.28 & 0.07 & 0.33 & 3.08 & 0.88 \\
\hline $\begin{array}{l}\text { automation } \\
\text { rate }\end{array}$ & 1.19 & 0.11 & 0.66 & 1.52 & 0.9 \\
\hline $\begin{array}{l}\text { growth } \\
\text { average }\end{array}$ & 1.13 & 0.15 & 0.82 & 1.21 & 0.41 \\
\hline $\begin{array}{l}\text { Turnover } \\
\text { receivables } \\
\text { rate }\end{array}$ & 0.99 & 0.27 & 0.92 & 1.08 & 0.46 \\
\hline $\begin{array}{l}\text { return on } \\
\text { investment }\end{array}$ & 1.03 & 0.23 & 0.32 & ------ & ------- \\
\hline
\end{tabular}

11.3 Autocorrelation among of the Independent Variables

Table (2) Indicates matrix of correlations between of independent variables, where it becomes apparent that there are only 3 statistical links out of 10 , two of them are weak $(-0.32,0.31)$ and the third is a strong inverse correlation (-0.71). In any case this is not enough to test the higher correlation among of the independent variables, so it has been a Test "Collinearity", and Table (1) Indicates results where the values vif of each of the independent variables is less than 5, which means that it has no self link problem among of independent variables, It is clear also that all values bigger than Tolerance $=0.04\left(1-\mathrm{R}^{2}\right)$, which confirms the absence of the problem of correlation among high self-of independent variables.

Table (2). Correlations between the independent variables

\begin{tabular}{|l|l|l|l|l|l|}
\hline \multicolumn{1}{|c|}{ Variable } & debt rate & $\begin{array}{l}\text { liquidity } \\
\text { ratio }\end{array}$ & $\begin{array}{l}\text { automation } \\
\text { rate }\end{array}$ & $\begin{array}{l}\text { growth } \\
\text { average }\end{array}$ & $\begin{array}{c}\text { Turnover } \\
\text { receivables } \\
\text { rate }\end{array}$ \\
\hline debt rate & 1.00 & $0.03-$ & $0.10-$ & 0.19 & $0.20-$ \\
\hline $\begin{array}{l}\text { liquidity } \\
\text { ratio }\end{array}$ & & 1.00 & $* 0.71-$ & $* 0.32-$ & $0.09-$ \\
\hline $\begin{array}{l}\text { automation } \\
\text { rate }\end{array}$ & & & 1.00 & $0.08-$ & $* 0.31$ \\
\hline $\begin{array}{l}\text { growth } \\
\text { average }\end{array}$ & & & & 1.00 & $0.01-$ \\
\hline $\begin{array}{l}\text { Turnover } \\
\text { receivables } \\
\text { rate }\end{array}$ & & & & & 1.00 \\
\hline
\end{tabular}

\subsection{The Independence of Errors}

Table (3) shows that the value of the Durbin-Watson $(\mathrm{d} *)$ amounted to 2.14 and tables Durbin-Watson statistical it when the number hits 12 , and independent variables 5 , the value, DU $=2.17$, and as long as the value of $(\mathrm{d} *)$ bigger than DU, there is no correlation between the problem of mistakes.

\subsection{Non-Falsity Regression Equation}

Found a lack of falsity in the regression equation as the value of $\mathrm{R}^{2}$ less than the value of Durbin-Watson, the Table 3 shows that the value of $\mathrm{d}^{*}=2.14$ and the value of $\mathrm{R}^{2}=0.96$ permission regression equation is the equation true and authentic. 


\section{Construction of the Regression Model}

Table (3) shows that the factors of independent variables (explanatory), in addition to the constant is of significance. That's where all levels of significance for viewing $(t)$ value less than 0.05 . That any transactions with as a significance values Where:

- Constant $=0.164$. It is the amount does not differ in any way.

- Debt Ratio $=$ Factor 0.291, which is a sign that the relationship of any direct correlation among the explanatory variable and the dependent variable (investment rate) Climate Debt Ratio by $100 \%$ certain direction and lead to a change in the investment rate, $29.1 \%$ of this amount in the same direction.

- Coefficient of Liquidity ratio $=-0.309$, which is negative which means that the inverse relationship among the explanatory variable and the dependent variable which is the rate of return on investment by altering the Ratio liquidity and a certain direction leads to a change in the rate of investment by $30.9 \%$ of this amount and contrary to the trend.

- Coefficient of Automation Ratio $=0.626$, which is positive and indicates that on the proportional relationship between the two variables and interpretive's, and Ratio change by automation and the direction of change leads to a certain rate of return on investment rate of $62.6 \%$ of this amount in the same direction.

- The growth rate coefficient $=0.524$, which is positive and therefore a direct correlation between this explanatory variable and the dependent variable, where the rate of change and growth by a particular direction resulting in a change in the rate of return on investment rate of $52.4 \%$ of this amount in the same direction.

- Coefficient of Rotating Rate of accounts receivable $=-0.386$, which is negative as the inverse relationship between the two variables and interpretive's The changed turnover of accounts receivable by a certain direction and lead to a change in the rate of investment by $38.6 \%$ of this amount, and contrary to the trend.

Note from the table that the level of significance also sights of the value of ( $F$ ) for your regression model was 0.00 , which means that a significant regression. The total coefficient of determination $\left(\mathrm{R}^{2}\right)$ 0.96, which means that the independent variables explain $96 \%$ of the changes in the dependent variable.

Table (3). Test of regression model

\begin{tabular}{|l|l|l|l|l|l|l|l|l|}
\hline & & $\begin{array}{l}\text { t- } \\
\text { value }\end{array}$ & $\begin{array}{l}\text { F - } \\
\text { value }\end{array}$ & $\begin{array}{l}\text { Sig } \\
\text { to(t -value) }\end{array}$ & $\begin{array}{l}\text { Sig } \\
\text { to( F -value) }\end{array}$ & R & R $^{2}$ & Durbin-Watson(d*) \\
\hline Constant & 0.164 & 6.60 & ------ & 0.00 & ----- & ----- & ------ & ------ \\
\hline debt rate & 0.291 & 2.40 & ----- & 0.02 & ----- & ----- & ------ & ----- \\
\hline $\begin{array}{c}\text { liquidity } \\
\text { ratio }\end{array}$ & $0.309-$ & $10.06-$ & ------ & 0.02 & ----- & ----- & ------ & ------ \\
\hline $\begin{array}{l}\text { automation } \\
\text { rate }\end{array}$ & 0.626 & 3.31 & ------ & 0.00 & ------ & ------ & ------- & ------ \\
\hline growth & 0.524 & 28.51 & ------ & 0.05 & ------ & ------ & ------- & ------- \\
\hline
\end{tabular}




\begin{tabular}{|l|l|l|l|l|l|l|l|l|}
\hline average & & & & & & & & \\
\hline $\begin{array}{l}\text { Turnover } \\
\text { receivables } \\
\text { rate }\end{array}$ & $0.386-$ & $13.31-$ & ------ & 0.00 & ----- & ------ & ------- & ------ \\
\hline Model & ----- & ------ & 45.50 & 0.00 & 0.00 & 0.98 & 0.96 & 2.14 \\
\hline
\end{tabular}

\section{The Regression Equation}

The Regression Equation is as Follows The average return on investment $=0.164+(0.291 \times$ Debt Ratio $)-(0.309 \times$ liquidity ratio $)+(0.626 \times$ percentage automation $)+(0.524 \times$ growth rate) - $(0.386 \times$ Rotating Rate accounts receivable $)$.

\section{Results}

The study found the following:

1-Regression model of dependent variable and the goal of the proceeds to invest in industrial companies in the city of Aqaba show that the independent variables explanatory which is a debt ratio, liquidity ratio, the percentage of automation, the growth rate and the rate of turnover of accounts receivable, all of the determinants of the dependent variable, and the explanatory variables determine the rate of $96 \%$ changes of return on investment.

2-There are three independent variables have a positive effect on the return on investment in industrial companies in the city of Aqaba .first of all is the ratio of debt and by (0.291) which means that the debt financing was meaningful and supportive of profitability, second is the percentage of automation and by (0.626) which means that the purchase of fixed assets and transformation from manual to the automatic raising of profitability, and finally the growth rate and by (0.524) which means that any increase in the value of sales improves profitability.

3-There are two variables independents have a negative impact on the return on investment in industrial companies in the city of Aqaba, first liquidity ratio and by $(-0.309)$, ie, that the increase in this ratio may miss the company's opportunities to increase profitability, and secondly Rotating Rate receivables and the value (-0.386) The reason back to the high value of futures sales and consequently to debt

4-Has proved that the regression model does not suffer from the problem of falsity nor correlations between errors. It turns out that the independent variables are divided normally, and that the independent variables saturated dependent variable, and that there is no correlation between high independent variables. This makes this form of honest and valid to predict.

\section{Recommendations}

The study recommends the following:

1-The industrial companies in the city of Aqaba buy assets on their own the account and not in cash, because the cost of debt is relatively few and the exploitation of the available liquidity in the production processes and therefore increase the proportion of debt for this 
purpose increases the return on investment.

2-On the industrial companies in the city of Aqaba try to rely more on fixed assets in its operations that raise productivity, where the proportion of automation leads to raise the return on investment.

3-The industrial companies in the city of Aqaba focus more on raise the value sales and warned to balance between the rate of positive growth and Rotating Rate of negative receivables.

4-The industrial companies in the city of Aqaba minimize as much as possible of the liquidity ratio which adversely affect the rate of return, and to exploit it in production processes.

5-The industrial companies in the city of Aqaba study the underlying causes of negative relationship between the rate of turnover of accounts receivable and the rate of return of investment to overcome them or mitigate them.

\section{References}

Abu Hashish, K. (2005). Cost accounting, Dar Wael Publishing, Amman, Jordan.

Abu-Nassar, M. (2010). Managerial accounting, Dar Wael Publishing, Amman, Jordan.

alqetha, M. (2008). The impact of capital structure on the profitability of Industrial Corporations Jordan, Unpublished MA Thesis, University of Yarmouk.

Aqudah, A. (2008). The Impact of Capital Structure on the Profitability of Jordanian Industrial Corporations, Unpublished MA Thesis, University of Yarmouk.

Atkinson. A. et. ( 2001). Management Accounting, 3ed Edition, prentice - hall, international Inc.

Bakri, S. (2000). Production and Operations Management, University House, Alexandria.

Basile, M. (2001). Managerial Accounting, Edition 3, Modern Library, Cairo.

Bodnar, G. (1995). and William S. Hopwood:,Accounting Information System, Englewood Cliffs, N. J. : Prentice-Hall .

Borass, N. (2012). Financial Constraints and Investment- Cash Flows Sensitivity: An Empirical Study of Manufacturing Firms Listed in Amman Boursa during the Period:2000-2009, Master Thesis in Yarmouk University, Unpublished MA Thesis, University of Yarmouk, [Online] Available: http://repository.yu.edu.jo/handle/123456789/2/search

Brien A. (1990). Management Information Systems, A Managerial End User Perspective, Irwin Homewood .

Brthick, A., \& West, Owen-D. (1987). Expert system - A new tool for professional. In Accounting Horizons, P. 9-16. 


\section{Macrothink}

Gryglewicz, S. (2008). Capital Stracture, Cash \& Payout Policy with Liquidity \& Solvency Concerns, Tilburg University.

Jaradat, H. (2012). The Impact of Inflation, Interest Rate, Workers' Remittances andLiquidity on Stock Returns in Amman Stock Exchange :During the Period of: 1980-2011. Unpublished MA Thesis, University of Yarmouk. [Online] Available: http://repository.yu.edu.jo/handle/123456789/2/search

Khharma, H., \& Qaqeesh, M. (2000). The factors affecting the profitability of insurance companies in Jordan: An Empirical Study. lighthouse, 5(1), 239-257.

Konstandina, V. (2007). Measuring Efficiency and Explaning Failures in Banking: Application to the Russian Banking Sector, Doctor of Philosophy Thesis, Oregon State University, United States.

Noi, F. (2010). Evaluating the efficiency of Algerian banks using financial ratios and cost limit random sample during the period (2004 -2008), Unpublished MA Thesis, University of Yarmouk. [Online] Available: http://repository.yu.edu.jo/handle/123456789/2/search

Sheikh H. et. (2007) The role of financial ratios in evaluating the performance of the economic project - An Empirical Study on companies Syrian Arab Electronic Industries. Tishreen University Journal for Studies and Scientific Research, 29(2), 131-150.

Tareq, M. (2012). The Impact of Investment Opportunities on Capital Structure: An Empirical Study of the Manufacturing Companies Listed inAmman Stock Exchange. Unpublished MA Thesis, University of Yarmouk. [Online] Available: http://repository.yu.edu.jo/handle/123456789/2/search 